\title{
SKH1-Hr hr
}

National Cancer Institute

\section{Source}

National Cancer Institute. SKH1-Hrhr. NCI Thesaurus. Code C98782.

An uncharacterized and non-pedigreed hairless albino mouse strain that is immunocompetent and euthymic. 